\title{
Kebijakan Pemerintah Daerah Dalam Penanggulangan Wabah Corona Virus Diease 2019 di Kabupaten Lamongan
}

\author{
Fahmi Anas \\ Universitas Airlangga Surabaya \\ Email: anasf412@gmail.com
}

\begin{abstract}
This study examines the policies of the Lamongan Regency government in preventing and overcoming the Covid-19 outbreak. Lamongan Regency Regulation No. 35 of 2020 concerning the prevention and control of Corona Virus 2019 in transition to recovery is one of the policies issued by the Lamongan Regency Government. This research aims to implement prevention and recovery policies in overcoming the Covid-19 outbreak in Lamongan Regency. The research method used is descriptive qualitative. The use of a qualitative approach in this research is descriptive analysis, the researcher wants to describe the policy of controlling and preventing Covid-19 in the transition to recovery in Lamongan Regency This research uses data sources from scientific journals, literature books, official websites which then come from descriptive analysis of prevention policies, and recovery in the response to the Covid-19 outbreak in Lamongan Regency. The results of the study explained that the prevention and control of the Corona Diease 2019 Virus in the transition to recovery in Lamongan Regency was the formation of a Covid-19 accelerated handling task force to accelerate the handling of Covid-19, the availability of health facilities and infrastructure for the Covid-19 test, quarantine or isolation areas, as well as massive close contact tracing. Prohibition of traveling without masks, guaranteeing goods vehicle activities and business operations (shops). The involvement of various parties has greatly helped government programs in overcoming Covid-19, such as the village head, community leaders and the interaction of the TNI and Polri which greatly helped create security and order during the prevention and recovery of Covid-19 countermeasures in Lamongan Regency.
\end{abstract}

Keywords: Policy, Corona Virus Diease 2019, Lamongan Regency. 


\section{Pendahuluan}

Pemerintah Indonesia dihadapkan pada situasi sulit terkait dengan pandemik covid 19 untuk menekan angka kematian penduduk yang terkena penyakit tersebut, dan dampak sosial ekonomi dari penyebarab virus. Kesigapan dan antisipasi penyebaran virus pada masa awal pandemik dipertanyakan banyak pihak. Paling tidak Badan Kesehatan Dunia (WHO) meragukan claim pemerintah bahwa Indonesia masih tergolong negara yang bebas penyebaran. Saat ini di seluruh dunia sedang terjadi sebuah pandemi yang mempunyai dampak cukup besar di semua sektor kehidupan manusia. World Health Organization (WHO) telah menetapkan Corona Virus Disease 2019 atau Covid-19 sebagai sebuah ancaman pandemi. Pengertian pandemi menurut Kamus Besar Bahasa Indonesia (KBBI) merupakan wabah yang berjangkit serempak di mana-mana atau meliputi geografi yang luas (Ristyawati, 2020).

Kasus Covid-19 muncul bermula terjadi di Wuhan, Tiongkok dan mulai menyebar ke hampir seluruh dunia. Penyebaran Covid-19 ini sangat cepat dan tidak ada yang mempu memprediksi kapan berakhirnya pandemi Covid-19 ini. Kasus Covid-19 yang merupakan pandemi global jelas menimbulkan kekhawatiran dari beragam kalangan, khususnya masyarakat. Kekhawatiran masyarakat semakin sangat terasa dengan melihat lonjakan kasus yang cukup cepat, dan melihat kurangnya kesiapan beberapa elemen yang cukup vital untuk "memerangi" Corona Virus Diease 2019. Melihat tingginya tingkat persebarannya yang begitu cukup mengharuskan pemerintah untuk segera mengambil langkah strategis. Dengan menetapkan kebijakan-kebijakan antisipatif untuk mengatasi dampak dari Covid-19 (Ristyawati, 2020).

Pandemi global yang terjadi saat ini jelas menimbulkan kekhawatiran masyarakat. Oleh karena itu, Pemerintah harus memberikan perlindungan kepada masyarakat dalam pencegahan maupun penanganan kasus Covid-19 sesuai amanat Undang-Undang Dasar Negara Republik Indonesia Tahun 1945. Semua Negara sangat gencar melakukan berbagai kebijakan karena adanya pandemi Corona Virus Diease 2019. Tak terkecuali Negara Indonesia, Indonesia kini kondisinya semakin memprihatinkan. Pemerintah Indonesia bahkan sudah menetapkan virus ini sebagai bencana non alam Covid-19 (Zahrotunnimah, 2020). Semua aspek kehidupan terkendala karena Covid-19. Ekonomi, Pariwisata, dan aspek lainnya 
mengalami penurunan drastis. Dengan kondisi seperti ini, pemerintah gencar membentuk kebijakan-kebijakan dalam memerangi pandemi Covid-19. Mengingat angka positif terjangkit Corona Virus Diease 2019 (Covid-19) mulai menunjukkan grafik naik. Tentu pemerintah tidak ingin angka positif terjangkit Covid-19 terus naik, melihat Indonesia secara letak geografis berbatasan langsung dengan negaranegara terdampak penularan Covid-19 (Suni, 2020).

Berbagai upaya dilakukan oleh berbagai Negara untuk menanggulangi penyebaran Corona Virus Diease 2019 (Covid-19) dan meminimalisir dampak yang ditimbulkannya, kebijakan yang diambil oleh banyak Negara yang terpapar Covid-19 terpusat kepada 2 (dua) kebijakan utama yaitu social distancing dan atau lockdown. Indonesia sebagai salah satu Negara yang terpapar Covid-19 melakukan kebijakan yang sama. Kasus Covid-19 yang merupakan pandemi global jelas menimbulkan kekhawatiran dari beragam kalangan, khususnya masyarakat. Melihat tingginya tingkat persebarannya yang begitu cukup mengharuskan pemerintah untuk segera mengambil langkah strategis.

Dengan menetapkan kebijakankebijakan antisipatif untuk mengatasi dampak dari Covid-19. Untuk menekan angka positif Covid-19, pemerintah mengeluarkan dasar hukum dan kebijakan untuk mempercepat penanganan Corona Virus Diease 2019 (Covid-19). Salah satunya adalah Pembatasan Sosial Berskala Besar atau PSBB yang diatur oleh PP nomor 21 tahun 2020. PSBB ini dapat menekan angka kerumunan massa yang dapat menjadi indikator penyebaran virus Covid 19. Penyebaran Covid-19 harus ditanggulangi secara cepat, karena diperkirakan 70\% masyarakat Indonesia dapat tertular, dan 1,5 juta lebih penduduk Indonesia akan meninggal apabila tidak ada respon, serta penanganan dari pemerintah (Harahap \& Bandung, 2020).

Kebijakan Pembatasan Sosial Berskala Besar (PSBB) adalah peraturan yang diterbitkan oleh Pemerintah, khususnya Kementerian Kesehatan (Kemenkes) dalam rangka melakukan percepatan penanganan pandemi Covid19 yang sedang mewabah. Pembatasan kegiatan masyarakat meliputi sekolah diliburkan dan perkantoran, pembatasan kegiatan di tempat keramaian atau fasilitas umum dan pembatasan khusus lainnya yang berkaitan dengan aspek keamanan. Efektivitas diberlakukannya PSBB dalam praktiknya di lapangan 
hanya akan sukses jika semua lapisan masyarakat

mengaplikasikan

pembatasan-pembatasan dan sesuai dengan protokol kesehatan yang telah ditetapkan oleh Pemerintah. Dengan demikian pemberlakuan PSBB mampu mengubah produktivitas setiap individu melalui perubahan institusional dan transformasi struktural yang terjadi di tengah-tengah masyarakat selama pemberlakuan PSBB (Awalia \& Nurwati, 2020).

Apabila dilihat dari beberapa tinjauan kebijakan PSBB yang dipilih oleh Pemerintah dalam menyikapi kasus Covid-19 yang ada saat ini, memang masih dalam proses pelaksanaan, namun memang di beberapa daerah di Indonesia juga ada yang mengalami perkembangan dengan kebijakan yang ada. Tetapi, jika dikaitkan dengan amanat UndangUndang Dasar Negara Republik Indonesia Tahun 1945, kebijakan PSBB banyak yang kurang efektif karena pasti masyarakat merasa bahwa belum mendapatkan perlindungan hukum dalam hal ini yaitu kebijakan yang ada yang dibuat oleh pemerintah saat ini. Terutama berkaitan dengan tanggungjawab negara terhadap kesehatan masyarakat dan tenaga medis khususnya yang ada pada Pasal $28 \mathrm{H}$ ayat
(1) dan Pasal 33 ayat (3) yang menjelaskan bahwa pelayanan kesehatan adalah hak setiap orang yang menjadi tanggungjawab negara atas penyediaannya. Setiap orang berhak dan wajib mendapat kesehatan dalam derajat optimal, tidak hanya menyangkut masalah individu tetapi meliputi semua faktor yang berkontribusi terhadap hidup yang sehat dan juga hak atas kesehatan serta hak atas pelayanan medis.

Pada saat ini, berdasarkan data pasien positif yang terkonfirmasi, kurva kasus Corona Virus Diease 2019 masih terus meningkat. Hal tersebut tentu sangat membuat masyarakat khawatir dan membuat kesan bahwa pemerintah belum sigap dalam menyelesaikan masalah Covid-19 ini. Diterapkannya kebijakan PSBB hanyalah salah satu pilihan dalam rangka melakukan tindakan mengurangi risiko bertambahnya korban. Seperti yang diketahui, bahwa kebijakan PSBB ditetapkan oleh pejabat yang berwenang dalam hal ini adalah Menteri yang menyelenggarakan urusan pemerintahan di bidang kesehatan. Pemerintah daerah dan pihak swasta harus tunduk pada PSBB yang ditetapkan Menteri. Tanpa mengabaikan pentingnya PSBB dalam penanganan wabah Covid-19. Penelitian 
ini menggambarkan bagaimana produktivitas setiap individu terus berjalan di tengah-tengah pandemi yang sedang mewabah (Awalia \& Nurwati, 2020). Banyak provinsi yang ikut melaksanakan PSBB, tidak terkecuali Provinsi Jawa Timur. Terkait dengan kebijakan yang telah dibuat oleh Gubernur yaitu Instruksi Gubernur jawa Timur No. 53 tahun 2020 tentang penerapan protokol kesehatan dalam pencegahan dan pengendalian Corona Virus Disease 2019 (Peraturan Gubernur, 2020). Provinsi Jawa Timur mengikuti pembatasan sosial, termasuk Kabupaten Lamongan.

Covid-19 meskipun baru ditemukan di Kota Wuhan China pada akhir tahun 2019 tetapi penyebarannya begitu cepat, hingga berselang 4 (empat) bulan setelah laporan kasus pertama yaitu pada bulan April 2020 setidaknya terdata lebih dari 200 Negara memiliki kasus Covid-19 dengan korban terinfeksi sebanyak 2.300.000 (dua juta tiga ratus) orang yang mana total kematian akibat Covid-19 lebih dari 150.000 (seratus lima puluh ribu) orang seluruh dunia (World Health Organization, 2020). Penyebaran Corona Virus Diease 2019 di Kabupaten lamongan di mulai April 2020, beberapa pekan pada bulan April dan Mei 2020 Kabupaten Lamongan sempat berada di peringkat tiga terbanyak (kasus Positif Covid-19) di Provinsi Jawa Timur (Yasa, 2020).

Ada beberapa kajian yang pernah membahas tentang Kebijakan Pemerintah terkait Corona Virus Diease 2019 (Pujaningsih dan Sucitawathi, 2020) mengatakan dalam penelitiannya Pemerintah Provinsi Bali menerapkan kebijakan Pembatasan Kegiatan Masyarakat (PKM). Munculnya Keppres No. 9 Tahun 2020, Presiden telah mendelegasikan kewenangannya pada setiap Gubernur untuk dapat lebih merespon aktif dan menciptakan kebijakan yang bermanfaat bagi daerahnya. Peraturan Walikota Denpasar Nomor 32 Tahun 2020 tentang Pembatasan Kegiatan Masyarakat di Desa, Kelurahan dan Desa Adat dalam Percepatan Penanganan Corona Virus Disease (Covid-19) merupakan salah satu kebijakan yang dibuat Pemerintah Kota Denpasar. Penerapan kebijakan PKM dalam penanggulangan wabah Covid-19 di Kota Denpasar sudah berjalan efektif. Keterlibatan pihak desa adat sangat membantu program Pemerintah Kota Denpasar.

Ristyawati (2020), penelitiannya tentang kebijakan Pembatasan Sosial Berskala Besar (PSBB) dalam penelitiannya mengatakan efektifitas 
kebijakan pemerintah pada masa pandemi dan bagaimana upaya yang dilakukan agar kebijakan yang diberikan selama masa Pandemi efektif sesuai UUD NRI Tahun 1945. Kebijakan PSBB banyak yang kurang efektif, upaya yang dilakukan agar kebijakan PSBB yang diberikan selama masa pandemi efektif sesuai UUD NRI Tahun 1945 Pemerintah Pusat dan Pemerintah Daerah memastikan keterbukaan informasi publik secara nyata, Pemerintah menjamin dan memastikan terutama kepada kaum menengah ke bawah mampu memenuhi kebutuhannya untuk menjamin hak atas hidup masyarakatnya dan tidak terkurangi suatu apapun harkat martabat masyarakatnya dan perlunya peran publik dalam hal saling menjaga, saling mengingatkan, dan saling membantu satu sama lain.

Berbicara mengenai kebijakan pemerintah terkait pandemi Corona Virus Disease 2019 (Covid-19), Pemerintah Daerah Kabupaten Lamongan menerbitkan kebijakan terkait pencegahan pandemi Corona Virus Disease 2019 (Covid-19). Peraturan diterbitkan oleh Pemerintah Kabupaten Lamongan, untuk itu dibuatlah Peraturan Pemerintah Kabupaten Lamongan Nomor 35 Tahun 2020 tentang pedoman pencegahan dan pengendalian Corona
Virus Diease 2019 dalam transisi darurat ke pemulihan Kabupaten Lamongan adalah dibentuknya gugus tugas percepatan penanganan (GTPP) Covid-19 untuk mempercepat penanganan Covid19.

Gugus Tugas Percepatan Penanganan Covid-19 Kabupaten Lamongan menggambil langkah percepatan atau akselerasi untuk mencapai target, Gugus Tugas Percepatan Penanganan (GTPP) Covid-19 Kabupaten Lamongan terus berupaya untuk meningkatkan kualitas pencegahan penyebaran Covid-19 melalui riset dan studi guna memperoleh strategi yang tepat. Untuk diketahui, Lamongan sebelumnya telah melakukan berbagai strategi untuk memutus penyebaran Covid-19. Di antaranya dengan mencari penderita sebanyak mungkin agar segera dapat tertangani, melakukan screaning, rapid massal menggunakan Afias 6 (enam), memperkuat tracing dan isolasi, serta melakukan test swap (Hidayat, 2020).

Perlu diketahui, berdasarkan data aplikasi Bersatu Lawan Covid-19 (BLC), 1 September 2020, Kabupaten Lamongan memiliki kasus terkonfirmasi positif 657 orang. Menurut Subuh (2020), angka kesembuhan berjumlah 538 orang dan 60 (enam puluh) orang meninggal. 
Kabupaten Lamongan terus bekerja keras untuk menekan angka penularan COVID-19. Meskipun Kabupaten Lamongan dalam jumlah akumulatif kematian mencapai 9.44 persen. Salah satu angkah Tim Gugus Tugas adalah memburu pelanggar-pelanggar protokol kesehatan. Kementerian Kesehatan (Kemenkes) berkolaborasi dengan semua lapisan masyarakat sehingga angka kematian Covid-19 bisa ditekan dan diperbaiki sampai pulih kembali.

Ada beberapa kendala dalam penanganan Covid-19 di Kabupaten Lamongan. Di antaranya adalah orang yang tertutup serta lupa telah melakukan kontak dengan siapa saja, serta kurangnya edukasi dan sosialisasi pada masyarakat (Santoso, 2020). Pemerintah Kabupaten Lamongan banyak melakukan edukasi pada masyarakat, pelaksanaan patroli lingkungan, serta cek poin. Menurut Muhammad Abid Khumaidi (2020) penanganan Covid-19 yang berlarut-larut bisa memunculkan impact sosial, ekonomi, dan politik.

Sementara terkait kegiatan perekonomian masyarakat, seperti kegiatan di pasar dan tempat pelelangan ikan, aturan diperketat sehingga semua pelaku ekonomi memperhatikan dan mentaati protokol kesehatan yang sudah di tetapkan oleh Pemerintah.
Keterlibatan berbagai pihak sangat membantu program pemerintah dalam menanggulangi Covid-19, seperti halnya pihak kepala desa dan tokoh masyarakat serta keterlibatan TNI dan Polri sangat membantu terciptanya keamanan serta ketertiban selama kegiatan pencegahan dan pemulihan penanggulangan Covid19 di Kabupaten Lamongan. Pemberian hukuman melalui sanksi administratif serta sanksi sosial dengan bantuan aparat petugas dan aparat desa dilakukan agar masyarakat disiplin mentaati protokol kesehatan dan tidak membuat kerumunan untuk memutus rantai penularan Covid-19.

Kebijakan dan peraturan harus diterbitkan oleh Pemerintah Kabupaten Lamongan, untuk itu dibuatlah Peraturan Pemerintah Kabupaten Lamongan Nomor 35 Tahun 2020 tentang pedoman pencegahan dan pengendalian Corona Virus Diease 2019 dalam transisi darurat ke pemulihan (Peraturan Bupati, 2020). Transisi darurat menuju pemulihan adalah salah satu langkah terbaik pemerintah Kabupaten Lamongan karena fokus utamanya adalah mengembalikan atau memperbaiki keadaan akibat Covid-19, diharapkan kebijakan bisa berjalan efektif membawa percepatan penanganan Covid-19. Sehingga pandemi cepat berlalu, 
kehidupan kembali normal, ekonomi kembali tumbuh dan masyarakat sejahtera. Adapun penelitian ini ingin melihat bagaimana penerapan dan langkah kebijakan pencegahan dan pengendalian Corona Virus Diease 2019 dalam transisi darurat ke pemulihan Kabupaten Lamongan.

\section{Kajian Pustaka}

Kebijakan Publik Menurut Michael Hill (1993:34) dalam (Sore, 2017) Kebijakan Publik merupakan suatu keputusan berdasarkan hubungan kegiatan yang dilakukan oleh aktor politik guna menentukan tujuan dan mendapat hasil berdasarkan pertimbangan situasi tertentu. Menurut Wahab (dalam Ramdhani, A., \& Ramdhani, 2016) menyatakan mengenai kebijakan publik bahwa:

1. Kebijakan publik merupakan suatu tindakan yang berorientasi pada pencapaian tujuan daripada sebagai perilaku.

2. Pada Hakekatnya kebijakan publik memiliki pola-pola tertentu tertentu yang mengarah pada pencapaian tujuan yang dilakukan oleh pemerintah, dan bukan merupakan keputusan yang berdiri sendiri.
3. Kebijakan publik berkenaan dengan tindakan atau aktivitas yang sengaja dilakukan secara sadar dan terukur oleh pemerintah dalam bidang tertentu.

4. Kebijakan publik dapat bersifat positif dalam arti kebijakan publik yaitu pedoman tindakan pemerintah dalam menghadapi suatu masalah tertentu, atau bersifat negatif yaitu keputusan elite politik untuk tidak melakukan sesuatu.

Kebijakan publik memberikan perhatian kepada masalah-masalah publik, sehingga untuk menyelesaikan masalah yang terjadi pemerintah memiliki alat yaitu sebuah kebijakan. Masalah publik terjadi apabila melibatkan banyak orang dan mempunyai akibat, dan akibat tersebut tidak terjadi pada orang-orang yang secara langsung terlibat, tetapi juga sekelompok orang lain yang secara tidak langsung terlibat. Setelah Perang Dunia II, kata policy mengandung arti kebijakan sebagai sebuah rationale, yaitu penilaian penuh pertimbangan. Sehingga menurut Wayne Parsons dalam (Suciati, 2017), kebijakan adalah usaha untuk 
mendefinisikan dan menyusun basis rasional untuk melakukan dan tidak melakukan suatu tindakan.

Menurut Woll, dalam kebijakan publik ada tiga hal yang berpengaruh sebagai tindakan pemerintah. Pertama, kebijakan yang dibuat oleh pemerintah untuk kehidupan masyarakat. Kedua, adanya output dalam bentuk program untuk masyarakat. Ketiga, adanya dampak kebijakan untuk kehidupan masyarakat. Kebijakan publik adalah kebutuhan mendasar dari masyarakat, karena dengan kebijakan publik dapat tercipta keteraturan dan kesejahteraan masyarakat. Kebijakan publik berkaitan dengan aturan yang dibuat oleh pemerintah dan dilaksanakan oleh sebuah negara. Ruang lingkup kebijakan publik sangat luas, bisa berbicara aspek pendidikan, kesehatan, ekonomi, maupun pertanian.

Kebijakan mengenai Pembatasan Sosial Berskala Besar (PSBB) di Indonesia untuk yang pertama kali diterapkan pada tanggal 10 April 2020 di Jakarta kemudian diikuti oleh beberapa daerah lainnya di Indonesia. Ada beberapa regulasi yang berkaitan dengan penerapan PSBB tersebut. Antara lain adalah Peraturan Pemerintah (PP) Nomor 21 Tahun 2020 tentang Pembatasan Sosial Berskala Besar Dalam
Rangka Percepatan Penanganan Corona Virus Disease 2019 (Covid-19), Peraturan Menteri Kesehatan (Permenkes) Nomor 9 Tahun 2020 tentang Pedoman Pembatasan Sosial Berskala Besar Dalam Rangka Percepatan Penanganan Corona Virus Disease 2019 (Covid-19), dan juga Peraturan Pemerintah Pengganti Undang-Undang (Perpu) Nomor 1 Tahun 2020 tentang Kebijakan Keuangan Negara dan Stabilitas Sistem Keuangan Untuk Penanganan Pandemi Corona Virus Disease 2019 dan atau dalam Rangka Menghadapi Ancaman yang Membahayakan Perkekonomian Nasional dan atau Stabilitas Sistem Keuangan.

Banyaknya kebijakan terkait PSBB yang tumpang tindih antara Pemerintah Pusat dengan Pemerintah Daerah yang disebabkann karena kurangnya koordinasi. Di satu sisi, Pemerintah Daerah lebih mengetahui kebutuhan dan karakteristik daerahnya karena Pemerintah Daerah merupakan pejabat publik yang sifatnya paling dekat dan lebih memahami betul masyarakat di wilayahnya. Di sisi lain, Pemerintah Pusat memiliki wewenang untuk mengeluarkan suatu kebijakan kedaruratan kesehatan yang mana mengakibatkan penerapan kebijakan 
PSBB dalam menyikapi adanya Covid-19 menjadi lebih lamban atau kurang sigap karena salah satunya adalah harus melalui mekanisme yang terlalu panjang.

Pada kenyataannya, penerapan PSBB di masing-masing daerah yang ada di Indonesia tentu berbeda-beda dan hal tersebut dapat ditinjau dari beberapa sisi. Dari sisi mekanisme syarat penerapan PSBB, tercantum dalam Peraturan Pemerintah Nomor 21 Tahun 2020 pada Pasal 2 yaitu :

(1) Dengan persetujuan menteri yang menyelenggarakan urusan pemerintahan di bidang kesehatan, Pemerintah Daerah dapat melakukan Pembatasan Sosial Berskala Besar atau pembatasan terhadap pergerakan orang dan barang untuk satu provinsi atau kabupaten atau kota tertentu.

(2) Pembatasan Sosial Berskala Besar sebagaimana dimaksud pada ayat (1) harus didasarkan pada pertimbangan epidemiologis, besarnya ancaman, efektifitas, dukungan sumber daya, teknis operasional, pertimbangan politik, ekonomi, sosial, budaya, pertahanan dan keamanan.
Selain itu, syarat yang harus dipenuhi oleh suatu daerah untuk mendapatkan ketetapan PSBB juga dipertegas dalam Permenkes Nomor 9 Tahun 2020 yang terdapat pada Pasal 2 : Untuk dapat ditetapkan Pembatasan Sosial Berskala Besar, suatu wilayah provinsi atau kabupaten atau kota harus memenuhi kriteria sebagai berikut: Jumlah kasus dan/atau jumlah kematian akibat penyakit meningkat dan menyebar secara signifikan dan cepat ke beberapa wilayah; dan Terdapat kaitan epidemiologis dengan kejadian serupa di wilayah atau negara lain (Ristyawati, 2020).

Kebijakan publik secara hierarki bisa bersifat nasional, regional, dan lokal. Bentuk-bentuk kebijakan publik juga beraneka ragam seperti Undang-Undang Dasar (UUD), Undang-Undang (UU) atau Peraturan Pemerintah Pengganti Undang-Undang (Perpu), Peraturan Pemerintah (PP), Peraturan Presiden (Perpres), Peraturan Daerah (Perda), dan lain-lain (Suciati, 2017). Instruksi Gubernur Jawa Timur No. 53 tahun 2020 tentang penerapan protokol kesehatan dalam pencegahan dan pengendalian Corona Virus Disease 2019 dan Peraturan Kabupaten Lamongan Nomor 35 Tahun 2020 tentang pedoman pencegahan dan pengendalian Corona Virus Diease 2019 
dalam transisi darurat ke pemulihan merupakan kebijakan yang dibuat Pemerintah Provinsi Jawa Timur serta Pemerintah Daerah Kabupaten Lamongan untuk menanggulangi penyebaran Corona Virus Diease 2019 melalui program pengendalian dan pencegahan Corona Virus Diease 2019.

Sebelum menetapkan sebuah kebijakan, pemerintah tentunya berdasar pada pertimbangan-pertimbangan hal yang bersifat komprehensif. Hal ini menjadi penting karena menentukan implikasi dan hasil dari penetapan kebijakan itu sendiri. Kebijakan merupakan rangkaian tindakan yang mempunyai tujuan tertentu yang diikuti dan dilaksanakan oleh seorang pelaku atau kelompok pelaku guna memecahkan suatu masalah tertentu (James E. Anderson). Istilah kebijakan publik lebih sering dipergunakan dalam kaitannya dengan tindakan-tindakan atau kegiatan pemerintah. Dapat pula disimpukan bahwa kebijakan publik merupakan rangkaian tindakan pemerintah yang bersifat mengatur dalam rangka merespons permasalahan yang dihadapi masyarakat dan mempunyai tujuan tertentu, berorientasi kepada kepentingan publik, dan bertujuan untuk mengatasi masalah, memenuhi keinginan dan tuntutan seluruh anggota masyarakat.

Penanganan masalah pandemi Covid-19 merupakan pekerjaan rumah yang tidak bisa dipandang sebelah mata bagi pemerintah (khususnya Pemerintah Kabupaten Lamongan). Banyak faktor yang perlu menjadi bahan pertimbangan untuk merumuskan kebijakan sebuah aturan. Semakin banyak data dan informasi sebagai bahan evaluasi rujukan pengambilan keputusan, semakin meminimalkan kemungkinan dampak buruk hasil sebuah kebijakan nantinya. Para ahli kebijakan publik memercayai bahwa hasil kebijakan yang buruk dapat disebabkan karena kebijakan itu sendiri tidak cukup baik dan atau kebijakan tersebut baik tapi tidak memungkinkan dalam tataran implementasinya. Analisis kebijakan itu sendiri memberikan informasi kepada pembuat kebijakan yang dapat dipergunakan untuk memecahkan masalah.

Kebijakan publik secara singkat diartikan oleh Dye (Islamy, 1994) sebagai"whatever goverments choose to do or not to do" yang merujuk pada respon tindakan pemerintah terhadap masalah publik. Sedangkan menurut Anderson (2006) kebijakan publik adalah berbagai tindakan atau kebijakankebijakan yang dikembangkan oleh 
badan-badan dan pejabat-pejabat pemerintah. Dalam konteks Covid-19, maka respon pemerintah Kabupaten Lamongan yang mewujudkan adanya kebijakan pengendalian dan pencegahan Corona Virus Diease 2019 dalam transisi darurat ke pemulihan di Kabupaten Lamongan sebagai upaya untuk menanggulangi penyebaran Covid-19 merupakan tindakan pemerintah dalam praktik kebijakan publik.

\section{Metode Penelitian}

Penelitian ini merupakan jenis penelitian deskriptif kualitatif. Pendekatan kualitatif dengan analisis deskrtiptif digunakan sebagai metode penelitian, alasan penggunaan metode analisis deskriptif didasarkan dengan adanya kesesuaian dengan tujuan penelitian yang ingin menggambarkan tentang penanggulangan dan pengendalian Covid-19. Penggunaan pendekatan kualitatif dalam penelitian melalui analisa deskriptif peneliti ingin menggambarkan penerapan kebijakan pengendalian dan pencegahan Corona Virus Diease 2019 dalam transisi darurat ke pemulihan di Kabupaten Lamongan. Analisa data dilakukan setelah mendapatkan data melalui penelitian kepustakaan yang disusun, dianalisa, dan disajikan untuk mendapatkan gambaran yang sistematis tentang penerapan kebijakan transisi darurat ke pemulihan di Kabupaten Lamongan dalam mencegah penyebaran Covid-19 di tengah masyarakat.

Studi dokumentasi digunakan sebagai teknik pengumpulan data untuk menggali data sekunder berupa dokumen-dokumen yang dianggap relevan dengan tema penanggulangan Covid-19 yang menjadi fokus kajian penelitian. Adapun dokumen tersebut terdiri dari jurnal ilmiah, literatur buku, situs website dan referensi lainnya. Teknik analisis data dilakukan melalui 3 (tiga) tahap kegiatan yang didsarkan pada konsep Creswell (2007) yaitu tahap reduksi data, penyajian data dam penarikan kesimpulan (Sugiyono, 2017).

\section{Isi dan Pembahasan}

Kebijakan publik adalah kebutuhan mendasar dari masyarakat, karena dengan kebijakan publik dapat tercipta keteraturan dan kesejahteraan masyarakat. Efektivitas upaya untuk mempercepat penanganan Covid-19 memerlukan dukungan dari semua pihak sehingga pandemi tersebut dapat cepat diatasi. Penanganan Covid-19 perlu dipercepat untuk menyelamatkan lebih banyak orang dari bahaya Covid-19 dan mempercepat juga pemulihan ekonomi. Upaya pemulihan ekonomi tidak efektif jika tidak ada dukungan dalam 
penanganan kesehatan. Untuk itu, sangat penting untuk dipahami bahwa penanganan kesehatan perlu ditangani terlebih dahulu hingga efektif sehingga upaya pemulihan ekonomi juga dapat diakselerasi (Yustinus, 2020).

Kebijakan pemerintah Kabupaten Lamongan menganai pencegahan dan pemulihan tentu juga perlu dukungan dan pengawasan. Gugus Tugas Percepatan Penanganan (GTPP) Covid-19 Kabupaten Lamongan terus berupaya untuk meningkatkan kualitas pencegahan penyebaran Covid-19 melalui penelitian dan studi untuk memperoleh strategi yang tepat. Tim Gugus Tugas mencari penderita sebanyak mungkin agar segera dapat tertangani, mencoba melakukan screaning, rapid massal menggunakan Afias 6, memperkuat tracing dan isolasi, serta melakukan tes swap. Upaya penanganan di Kabupaten Lamongan terlihat lebih sistematis dibandingkan Wilayah atau Kabupaten lain, hal ini ditandai dengan langkah Pemerintah membangun fasilitas isolasi untuk penderita Covid-19. Dalam menangani Covid-19 Pemerintah Kabupaten Lamongan menilai bahwasannya semakin cepat diketahui kasus positif dalam jumlah banyak, bisa cepat tracing, bisa cepat surveillance, penatalaksanaan pun menjadi semakin bagus dan akurat.

Koordinator bidang preventif dan Promotif Satgas Penanganan Covid-19 Kabupaten Lamongan (Hidayat, 2020) mengungkapkan Swab Test dan PCR menjadi metode dan langkah yang langsung di rekomendasikan oleh World Health Organization (WHO). Gugus Tugas Percepatan Penanganan Covid-19 Kabupaten Lamongan mencoba memperkuat prosedur pengendalian, Pemerintah Kabupaten Lamongan memanfaatkan Swab Test tidak lagi menggunakan Rapid Test. Swab Test dirasa menjadi pilihan utama karena dianggap mempunyai hasil yang lebih akurat. Pemerintah Kabupaten Lamongan selain menggunakan Swab Test juga menggunakan PCR dengan kapasitas 70 sampel setiap harinya. Keakuratan Swab test dan PCR diharapkan kedepan mampu mendapatkan temuan yang berkualitas sehingga memudahkan tracing dan isolasi untuk memutus rantai penularan Covid-19 di Kabupaten Lamongan.

Keseriusan pemerintah Kabupaten Lamongan menangani Covid19 juga diperlukan solidaritas masyarakat Lamongan. Menurut koordinator bidang preventif dan Promotif Satgas Penanganan Covid-19 
Kabupaten Lamongan Hidayat (2020), bahwasannya Peningkatan tracing dan scrining juga harus diikuti oleh masyarakat untuk melakukan isolasi dan kepatuhan pada protokol kesehatan, kerja sama antara gugus tugas percepatan penanganan (GTPP) dengan masyarakat diharapkan penularan Covid19 di Kabupaten Lamongan bisa ditekan, memberikan perlindungan, keamanan, kenyamanan pada masyarakat Kabupaten Lamongan.

Selain melakukan langkah penelusuran kontal erat atau tracing dengan cepat pada masyarakat yang terkonfirmasi tertular Covid-19, Gugus Tugas Percepatan Penangan (GTPP) Covid-19 juga melakukan sosialisasi pada masyarakat Kabupaten Lamongan mengenai pentingnya memutus rantai penularan Covid-19 dengan mematuhi protokol kesehatan, memakai masker, menjaga kebersihan, pembatasan aktivitas atau mobilitas masyarakat, mengindari kerumunan. Kebijakan pemerintah Kabupaten Lamongan menganai pencegahan dan pemulihan tentu juga perlu dukungan dan pengawasan. Dari kebijakan ini dilakukan pengawasan, seperti wajib memakai masker saat keluar dari rumah bagi masyarakat. Hal ini perlu diawasi karena pemakaian masker dapat meminimalisir penularan Covid-19.

Kebijakan publik menurut Anderson (2006) adalah berbagai tindakan atau kebijakan-kebijakan yang dikembangkan oleh badan-badan dan pejabat-pejabat pemerintah. Dalam konteks Covid-19, maka respon pemerintah Kabupaten Lamongan yang membuat peraturan atau kebijakan mengenai pengendalian dan pencegahan Corona Virus Diease 2019 dalam transisi darurat ke pemulihan di Kabupaten Lamongan adalah sebagai upaya untuk menanggulangi penyebaran Corona Virus Diease 2019 merupakan salah satu tindakan pemerintah dalam praktik kebijakan publik.

Implementasi kebijakan publik dalam perkembangannya memiliki banyak model dan tujuan untuk melihat sejauh mana kebijakan tersebut dijalankan dan faktor-faktor apa saja yang menjadi pendorong dan penghambat pelaksanaan kebijakan tersebut. Grinlde (1980) mengungkapkan bahwa implementasi kebijakan dipengaruhi oleh isi kebijakan (content of the policy) dan lingkungan kebijakan (context of the policy). Edward III (Tachjan, 2008) mengungkapkan implementasi kebijakan publik dipengaruhi oleh faktor komunikasi, 
sumber daya, disposisi dan struktur birokasi.

Kebijakan transisi darurat menuju pemulihan adalah salah satu langkah terbaik pemerintah Kabupaten Lamongan karena fokus utamanya adalah mengembalikan atau memperbaiki keadaan akibat Covid-19. Pemerintah Kabupaten Lamongan melakukan berbagai upaya untuk memulihkan kembali aktivitas normal masyarakat Kabupaten Lamongan ditengah-tengah pandemik Covid-19. Pemerintah Kabupaten Lamongan selain membentuk Gugus Tugas Percepatan Penanganan Covid-19, Pemerintah Kabupaten Lamongan bekerjasama dengan Kementerian PUPR untuk membangun tempat atau fasilitas Isolasi Covid-19 untuk masyarakat Kabupaten Lamongan. Fasilitas Isolasi Covid-19 dibangun dengan perencanaan dan pelaksanaan yang cepat.

$$
\text { Covid-19 meskipun baru }
$$
ditemukan di Kota Wuhan China pada akhir tahun 2019 tetapi penyebarannya begitu cepat, hingga berselang 4 (empat) bulan setelah laporan kasus pertama yaitu pada bulan April 2020 setidaknya terdata lebih dari 200 Negara memiliki kasus Covid-19 dengan korban terinfeksi sebanyak 2.300.000 (dua juta tiga ratus) orang yang mana total kematian akibat
Covid-19 lebih dari 150.000 (seratus lima puluh ribu) orang seluruh dunia (World Health Organization, 2020).

Penyebaran Corona Virus Diease 2019 di Kabupaten lamongan di mulai April 2020, beberapa pekan pada bulan April dan Mei 2020 Kabupaten Lamongan sempat berada di peringkat tiga terbanyak (kasus Positif Covid-19) di Provinsi Jawa Timur. Menurut Yasa (2020) meningkatnya kasus Covid-19 di Kabupaten Lamongan menjadi perhatian tersendiri bagi pemerintah untuk membagun tempat atau fasilitas yang mendukung untuk menampung masyarakat yang terpapar Covid-19. Keberadaan fasilitas isolasi diharapkan mampu memutus rantai penyebaran Covid-19 di Kabupaten Lamongan.

Pembangunan fasilitas ruang isolasi atau observasi di Kabupaten Lamongan di mulai pada 1 Mei 2020 dan selesai pada 3 Juni 2020. Keberadaan fasilitas isolasi atau observasi diharapkan bisa membantu menangani dan penyembuhan Covid-19 untuk masyarakat Kabupaten Lamongan. Dalam rapat virtual wakil Menteri PUPR John Wempi Wetipo mengungkapkan bahwasannya pembangunan fasilitas dan observasi di Lamongan mempunyai nilai yang strategis dan mampu memberi nilai 
besar terhadap penanganan penyebaran Covid-19 di Kabupaten Lamongan. Komitmen dan soliditas Pemerintah dalam menangani penyebaran Covid-19 diharapkan mampu mempercepat penanganan Covid-19.

Rumah sakit atau fasilitas isolasi memiliki daya tamping 82 (delapan puluh dua) pasien dengan ruang perawatan yang terpisah. Bangunan karantina 2 (dua) terdiri dari 50 (lima puluh) tempat tidur observasi, ruang tindakan dan ruang dokter. Bangunan isolasi terdiri dari 7 (tujuh) tempat tidur, ruang dokter dan perawat. Bangunan satelit terdiri dari ruang sterilisasi, gizi, laundri, alat medis dan farmasi. Pembangunan rumah sakit ini bersifat permanen sehingga pasca pandemi Covid-19, keberadaan rumah sakit ini masih bisa dimanfaatkan untuk rumah sakit infeksi dan yang lain (Kencana, 2020).

Keseriusan

Pemerintah

Kabupaten Lamongan dalam melakukan pencegahan dan pemulihan terlihat, terbukti dengan begitu cepatnya merespon wabah Covid-19 dengan membuat kebijakan Pemulihan, Pembentukan Gugus Tugas percepatan pencegahan beserta membangun fasilitas isolasi atau observasi yang begitu cepat. Sebelumnya Kabupaten Lamongan belum memiliki rumah sakit standar untuk penanganan Covid-19. Respon cepat dari Pemerintah Kabupaten Lamongan beserta Menteri PUPR dalam pembangunan fasilitas isolasi atau observasi merupakan langkah kongrit untuk melakukan pencegahan dan pemulihan Covid-19 di Kabupaten Lamongan.

Berbagai upaya dilakukan oleh berbagai Negara untuk menaggulangi penyebaran Covid-19 dan meminimalisir dampak yang ditimbulkannya. Pemerintah Kabupaten Lamongan mencoba untuk menanggulangi penyebaran Covid-19 dengan diterbitkannya Peraturan Kabupaten Lamongan No. 35 Tahun 2020 tentang pedoman pencegahan dan pengendalian Corona Virus Diease 2019 dalam transisi darurat ke pemulihan (Peraturan Bupati, 2020). Dalam menangani Covid-19 Pemerintah Kabupaten Lamongan menilai bahwasannya semakin cepat diketahui kasus positif dalam jumlah banyak, bisa cepat tracing, bisa cepat surveillance, penatalaksanaan pun menjadi semakin bagus dan akurat.

Selain melakukan langkah penelusuran kontal erat atau tracing dengan cepat pada masyarakat yang terkonfirmasi tertular Covid-19, Gugus Tugas juga melakukan sosialisasi pada 
masyarakat Kabupaten Lamongan mengenai pentingnya memutus rantai penularan Covid-19 dengan mematuhi protokol kesehatan, memakai masker, menjaga kebersihan, pembatasan aktivitas atau mobilitas masyarakat, mengindari kerumunan. Kebijakan pemerintah Kabupaten Lamongan menganai pencegahan dan pemulihan tentu juga perlu dukungan dan pengawasan. Dari kebijakan ini dilakukan pengawasan, seperti wajib memakai masker saat keluar dari rumah bagi masyarakat. Hal ini perlu diawasi karena pemakaian masker dapat meminimalisir penularan Covid-19.

Selain dilakukannya pengawasan tentang pemakaian masker, dilakukan juga pengawasan mengenai mobilisasi masyarakat. Mobilisasi masyarakat yang dimaksud adalah masyarakat yang keluar atau masuk dari tingkat wilayah sampai desa. Mobilisasi masyarakat menjadi indikator terjadinya penularan Covid-19 karena masyarakat berpindah dari satu tempat ke tempat lainnya. Oleh karena itu untuk mencegah dan pemulihan, Gugus Tugas dan Pemerintah menerbitkan kebijakan pembatasan kegiatan, baik pembatasan kegiatan yang dilakukan mulai bekerja dari rumah (work from home), belajar dari rumah (study from home), pembatasan kegiatan agama dan pembatasan kegiatan di tempat umum lainnya.

Dukungan dan pengawasan pada masyarakat terkait protokol kesehatan menjadi tugas bagi semua masyarakat, tidak hanya Gugus Tugas dan Pemerintahan Kabupaten. Gugus Tugas yang dibentuk Pemerintah Daerah Kabupaten Lamongan membuat inisiatif membangun kerjasama dengan semua pihak mengenai dukungan dan pengawasan kepatuhan masyarakat terkait protokol kesehatan. Tim Gugus Tugas dan Pemerintah membangun kerja sama dengan Dinas Kesehatan, TNI, Polri, Pemerintah Kecamatan, Kepala Desa dan Tokoh masyarakat untuk pencegahan dan pemulihan Kabupaten Lamongan dari wabah Covid-19.

Tempat umum seperti restoran, rumah makan, cafe, pedagang kaki lima usaha makanan dan minuman, dan mall diperbolehkan buka hanya sampai jam 9 (Sembilan) malam serta telah dilakukan pengawasan ketat pada semua unit usaha tersebut. Setelah jam 9 (sembilan) malam akan dilakukan patroli jika masih ada tempat-tempat umum seperti restoran, rumah makan, cafe, pedagang kaki lima usaha makanan dan minuman, dan mall masih ada yang beroperasi, maka akan dikenakan sanksi larangan berjualan. Pembatasan operasi tempat- 
tempat umum menjadi salah satu fokus untuk diperhatikan karena tempat umum menjadi salah satu pusat tempat berkerumun masyarakat.

$$
\text { Selanjutnya }
$$

pembatasan

kerumunan masyarakat juga sangat diawasi saat pelaksanaan pencegahan dan pemulihan di Kabupaten Lamongan. Kerumunan masyarakat dianggap dapat menjadi sumber penularan Covid-19 karena berkumpulnya masyarakat dalam jumlah yang banyak. Pembatasan terhadap kerumunan ini dilakukan melalui pembatasan jumlah (kuantitas) masyarakat pada satu tempat. Jumlah (kuantitas) yang dimaksud adalah jumlah masyarakat yang menuju tempat yang biasanya menimbulkan kerumunan masa dibatasi. Dan dianjurkan untuk beralih ke online demi menghindari adanya kerumunan masa melalui metode phsycal distancing .

Pembatasan ini perlu dilakukan karena melibatkan banyak masyarakat dan seringkali tersebut tidak mematuhi protokol kesehatan. Terdapat juga sanksi yang akan dikenakan terhadap masyarakat yang melanggar yaitu sanksi administratif dan sanksi sosial dengan bantuan TNI, Polri, Pemerintah Kecamatan, Kepala Desa dan Tokoh masyarakat untuk pencegahan dan pemulihan Kabupaten Lamongan dari wabah Covid-19. Sanksi ini dibuat bukan untuk menakuti masyarakat namun untuk keamanan dan kebaikan masyarakat secara keseluruhan. Pentingnya solidaritas dan kerjasama serta kesadaran dari masyarakat mengenai kedisiplinan di situasi pandemi saat ini.

Sanksi administratif dan sanksi sosial pada setiap masyarakat yang melanggar ketentuan kebijakan Pemerintah Kabupaten Lamongan terkait pencegahan dan pemulihan Covid-19 akan diberikan teguran berupa teguran lisan, perintah berupa keharusan membeli masker, perintah untuk tidak melanjutkan perjalanan, dan tidak dilayani dalam pengurusan administrasi yang lainnya. Sedangkan sanksi sosial ini diatur sesuai dengan sosial budaya setiap lingkungan masing-masing. Jadi setiap desa menentukan sanksi sosial sesuai dengan desa masing-masing. Komitmen dan kerja sama yang kuat antara Pemerintah Kabupaten Lamongan dengan bantuan TNI, Polri, Pemerintah Kecamatan, Kepala Desa dan Tokoh masyarakat beserta masyarakat menjadi kunci keberhasilan Kabupaten Lamongan dalam menanggulangi pencegahan dan pemulihan Kabupaten Lamongan.

Kebijakan Pemerintah Kabupaten Lamongan transisi menuju pemulihan 
implementasinya membutuhkan solidariritas semua actor masyarakat Kabupaten Lamongan. Sesuai dengan konsep kebijakan yaitu diciptakan untuk menyelesaikan masalah publik, kebijakan dirumuskan atas dasar rasionalitas dan penuh dengan pertimbangan agar tidak menimbulkan polemik atau permasalahan baru. Setiap kebijakan yang dibuat pemerintah berisi aturan atau larangan yang mampu menciptakan keteraturan dan ketertiban untuk semua lapisan masyarakat.

Menurut Mazmanian dan Sabatier (Winarno, 2008) mengungkapkan bahwasannya implementasi dipengaruhi oleh karakteristik dari masalah (tractability of the problems), karakteristik kebijakan atau undangundang (ability of statute to structure implementations), variabel lingkungan (nonstatutory variables affecting implementation). Berdasarkan pemahaman diatas, konsep implementasi kebijakan pada dasarnya memiliki tiga faktor yang harus dipenuhi, yaitu: substansi atau isi kebijakan yang rinci, adanya pelaksana dan adanya sasaran. Jika dikaitkan dengan konsep implementasi kebijakan peraturan pencegahan dan pengendalian dari transisi darurat menuju pemulihan sebagai upaya penanggulangan Covid-19 harus di dasarkan tiga unsur tersebut. Peraturan Kabupaten Lamongan Nomor 35 Tahun 2020 tentang pedoman pencegahan dan pengendalian Corona Virus Diease 2019 dalam transisi darurat menuju pemulihan merupakan kebijakan yang dibuat Pemerintah Daerah Kabupaten Lamongan untuk menanggulangi penyebaran Corona Virus Diease 2019 merupakan substansi kebijakan.

Berdasarkan pada konteks implementasi Peraturan Kabupaten Lamongan Nomor 35 Tahun 2020 tentang pedoman pencegahan dan pengendalian Corona Virus Diease 2019 dalam transisi darurat menuju pemulihan Kabupaten Lamongan, pelaksana atau implementor adalah Pemerintah Daerah, Gugus Tugas, TNI, Polri, Pemerintah Kecamatan, Kepala Desa dan Tokoh masyarakat. Sedangkan kelompok sasaran dalam konteks Peraturan Kabupaten Lamongan Nomor 35 Tahun 2020 tentang pedoman pencegahan dan pengendalian Corona Virus Diease 2019 dalam transisi darurat menuju pemulihan Kabupaten Lamongan adalah semua lapisan masyarakat Kabupaten Lamongan.

Dengan kebijakan transisi menuju pemulihan ini dapat dikatakan sebagai pencapaian tujuan pemerintah dalam 
menciptakan keteraturan dan ketertiban masyarakat dapat terwujud. Sesuai dengan konsep kebijakan yaitu kebijakan dibuat dengan tujuan tertentu di masyarakat dan kebijakan diciptakan untuk mengatasi permasalahan public atau masyarakat dengan tujuan dapat mencapai kesejahteraan masyarakat melalui peraturan yang dibuat pemerintah. Maka pemerintah dengan sigap memperhatikan keselamatan masyarakatnya dengan membuat peraturan atau kebijakan pencegahan dan pengendalian Covid-19 dari transisi menuju pemulihan. Kegiatan pencegahan dan pemulihan ini selain memiliki tujuan mengamankan masyarakat, juga bertujuan menekan angka penularan Covid-19 di Kabupaten Lamongan. Dengan diberlakukannya kebijakan pencegahan dan pemulihan ini tentu mampu perlahan-lahan mengurangi angka penularan hingga Kabupaten Lamongan menjadi Kabupaten atau zona bersih bebas Covid-19.

\section{Kesimpulan}

Peraturan Kabupaten Lamongan Nomor 35 Tahun 2020 tentang pedoman pencegahan dan pengendalian Corona Virus Diease 2019 dalam transisi darurat ke pemulihan merupakan kebijakan yang dibuat Pemerintah Daerah Kabupaten Lamongan untuk menanggulangi penyebaran Corona Virus Diease 2019. Kebijakan pencegahan dan pemulihan ini selain memiliki tujuan mengamankan masyarakat, juga bertujuan menekan angka penularan Covid-19 di Kabupaten Lamongan. Dengan diberlakukannya kebijakan pencegahan dan pemulihan ini diharapkan mampu perlahan-lahan mengurangi angka penularan hingga Kabupaten Lamongan menjadi Kabupaten atau zona bersih bebas Covid19. Program dan langkah Pemerintah Kebupaten Lamongan dalam mengendalikan dan pemulihan adalah membentuk gugus tugas percepatan penanganan (GTPP) Covid-19. Pemerintah Kabupaten Lamongan terus berupaya untuk meningkatkan kualitas pencegahan penyebaran Covid-19 melalui penelitian dan studi untuk memperoleh strategi yang tepat serta Tim Gugus Tugas mencari penderita sebanyak mungkin agar segera dapat tertangani, mencoba melakukan screaning, rapid massal, memperkuat tracing dan melakukan tes swap serta isolasi. Pemerintah Kabupaten Lamongan bekerjasama dengan Kementerian PUPR untuk membangun fasilitas isolasi atau observasi dalam rangka penanganan Covid-19. Fasilitas yang mendukung untuk menampung masyarakat yang terpapar Covid-19. Keberadaan fasilitas 
isolasi diharapkan mampu memutus rantai penyebaran Covid-19 di Kabupaten Lamongan. Untuk mencegah dan pemulihan, Gugus Tugas dan Pemerintah menerbitkan kebijakan pembatasan kegiatan, baik pembatasan kegiatan yang dilakukan mulai bekerja dari rumah (work from home), belajar dari rumah (study from home), pembatasan kegiatan agama dan pembatasan kegiatan di tempat umum lainnya. Komitmen dan kerja sama yang kuat antara Pemerintah Kabupaten Lamongan dengan bantuan TNI, Polri, Pemerintah Kecamatan, Kepala Desa dan Tokoh masyarakat beserta masyarakat menjadi kunci keberhasilan Kabupaten Lamongan dalam menanggulangi pencegahan dan pemulihan Kabupaten Lamongan. Patroli dan adanya sanksi administratif serta sanksi sosial bagi masyarakat yang melanggar protokol kesehatan menjadi salah satu inisiatif Pemerintah Kabupaten Lamongan.

\section{Daftar Pustaka}

Andersen, J.E. (2006). Public Policy Making. New York: Holt Renehart. \& Wiston.

Creswell, J.W. (2007). Qualitative Inquiry and Reseach Design: Choosing Among Five Approaches. Thousand Oaks: Sage Publications.
Grindle, M.S (1980). Politics and Policy Implementation in The Third World. New Jersey: Princeton University press.

Islamy, M.I. (1994). Prinsip-prinsip Perumusan Kebijakan Negara. Jakarta: Bumi Aksara.

Peraturan Bupati Lamongan Nomor 35 Tahun 2020. Tentang Perubahan Atas Peraturan Bupati Nomor 28 Tahun 2020 Tentang Pedoman Pencegahan dan Pengendalian Corona Virus Disease 2019 Dalam Status Transisi Darurat Menuju Pemulihan.

Peraturan Gubernur Jawa Timur Nomor 53 Tahun 2020 Tentang Penerapan Protokol Kesehatan Dalam Pencegahan Dan Pengendalian Corona Virus Disease 2019.

Sore, U. B. dan S. (2017). Kebijakan Publik. Makassar: CV Sah Media. Sugiono, Prof Dr. (2017). Metode Penelitian Kualitatif. Bandung: Alfabeta.

Tachjan. (2008). Implementasi Kebijakan Publik. Bandung: AIPI BandungPuslit.

Winarmo, B (2008). Kebijakan Publik: Teori dan Proses. Jakarta: PT. Buku Kita. 
World Healt Organization. (2020). Coronavirus Disease (Covid-19). Pandemic. Geneva.

\section{Sumber Jurnal}

Awalia, N., \& Nurwati, N. (2020). Efektivitas Produktivitas Keluarga Ditengah Tengah Pembatasan Sosial Berskala Besar Selama Covid 19.

Harahap, D. A., \& Bandung, U. I. (2020). Pembatasan Sosial Berskala Besar (PSBB) Menangani Pandemi Covid-19 dan Tren Pembelian Online.

Ramdhani, A., \& Ramdhani, M. A. (2016). Konsep Umum Pelaksanaan Kebijakan Publik. Jurnal Publik, 11(1), 1-12.

Ristyawati, Aprista. (2020). Efektifitas Kebijakan Pembatasan Sosial Berskala Besar Dalam Masa Pandemi Corona Virus 2019 oleh Pemerintah Sesuai Amanat UUD NRI Tahun 1945. Administrative Law \& Governance Journal. Volume 3 Issue 2, June 2020, 240.

Suciati, A. (2017). Kebijakan Publikdan Partisipasi Masyarakat (Implementasi Perda No. 15 Tahun 2011 tentang Pengelolaan Sampah di Kota Bekasi terhadap TPA Sumur Batu).
Sucitawathi P, Dewi, Pujaningsih, Nyoman. (2020). Penerapan Kebijakan Pembatasan Kegiatan Masyarakat (PKM) Dalam Penanggulangan Wabah Covid-19 Di Kota Denpasar. Jurnal MODERAT, Volume 6, No 3 ISSN: 24423777.

Suni, N. S. P. (2020). Kesiapsiagaan Indonesia Menghadapi Potensi Penyebaran Corona. Pusat PenelitianBadan Keahlian DPR RI, XII(3), 13-18. Diterbitkan, Ciamis: Program Pascasarjana FISIP UNIGAL.

Zahrotunnimah, Z. (2020). Langkah Taktis Pemerintah Daerah Dalam Pencegahan Penyebaran Virus Corona Covid-19 di Indonesia. SALAM: Jurnal Sosial Dan Budaya Syar-I, 7(3).

\section{Sumber Website}

https://lamongankab.go.id/2020/05/06 Lupaya-gugus-tugas-percepatanpenanganan-gtpp-covid-19-kablamongan-meningkatkankualitas-pencegahanpenyebaran-covid-19.html

https://www.antaranews.com/berita/16 95994/pemerintah-efektivitaspenanganan-covid-19-perludukungan-semua-pihak 
Jurnal Politik dan Sosial Kemasyarakatan

Vol 13 No 1 (2021) : Februari 2021

https://www.merdeka.com/uang/pemer

intah-resmikan-fasilitas-

observasi-dan-isolasi-covid-19-

di-lamongan.html

Tekan Kematian COVID-19 Kabupaten

Lamongan, Kemenkes Siap

Terjunkan Tim - Health

Liputan6.com 